\title{
Penerapan Model Scramble untuk Meningkatkan Kemampuan Belajar Tematika Muatan IPA pada Siswa Kelas V (Lima) SDN Koncer 1 Tenggarang Bondowoso Tahun 2020
}

\author{
Diterima: \\ 2 Januari 2021 \\ Revisi: \\ 15 Januari 2021 \\ Terbit: \\ 1 Februari 2021
}

\author{
Said Farika Sari \\ SDN Koncer 1 Tenggarang Bondowoso \\ Bondowoso, Indonesia \\ E-mail:aidfarikasari@gmail.com
}

\begin{abstract}
Abstrak - Penelitian ini diharapkan dapat meningkatkan hasil belajar siswa pada pembelajaran IPA, khususnya materi unsur, senyawa dan, campuran dalam kehidupan sehari-hari melalui penerapan model Scramble. Hal tersebut bertujuan untuk mencari solusi permasalahan yang dihadapi peneliti dengan melakukan perbaikan proses pembelajaran dengan penerapan metode Sramble. Dalam penelitian tindakan kelas dilakukan sebanyak 2 siklus, setiap siklus terdapat beberapa kendala serta kelemahan, namun dapat diatasi dengan baik sehingga kriteria ketuntasan minimal ditetapkan dapat tercapai. Data penelitian diperoleh melalui penugasan kelompok sebagai data utama dan lembar evaluasi diakhir siklus sebagai data pendukung untuk mengukur tingkat keberhasilan siswa dalam proses pembelajaran. Pada akhir siklus diperoleh peningkatan hasil belajar siswa melalui penerapan metode Scramble. Hasil tersebut menunjukkan adanya peningkatan dari siklus sebelumnya. Berdasarkan hasil penelitian tersebut dapat disimpulkan bahwa penggunaan Model Scramble dapat meningkatkan hasil belajar siswa pada pembelajaran IPA materi unsur, senyawa, dan campuran. Dalam penerapan model scramble selain meningkatkan hasil belajar siswa pada pembelajaran IPA juga dapat mengubah kondisi kelas menjadi lebih kondusif dan menyenangkan.
\end{abstract}

Kata Kunci- model scramble, hasil belajar, tematik muatan IPA

Abstract - This research is expected to improve student learning outcomes in science learning, especially elements, compounds and mixtures in everyday life through the application of the Scramble model. It aims to find solutions to problems faced by researchers by improving the learning process by applying the Scramble method. In class action research, 2 cycles were carried out, each cycle had several obstacles and weaknesses, but they could be overcome properly so that the minimum completeness criteria set could be achieved. The research data was obtained through group assignments as the main data and the evaluation sheet at the end of the cycle as supporting data to measure the level of student success in the learning process. At the end of the cycle, students' learning outcomes were obtained through the application of the Scramble method. These results indicate an increase from the previous cycle. Based on the results of these studies, it can be concluded that the use of the Scramble Model can improve student learning outcomes in science learning for elements, compounds, and mixtures. In the application of the scramble model, in addition to improving student learning outcomes in science learning, it can also change class conditions to be more conducive and fun.

Keywords - scramble model, learning outcomes, science content thematic 
PTK, Vol.2 No.1 2021

ISSN: 2747-1977 (Print) / 2747-1969 (Online)

DOI: https://doi.org/10.53624/ptk.v2i1.42

\section{PENDAHULUAN}

Belajar merupakan suatu proses perubahan tingkah laku yang membutuhkan dorongan atau motivasi untuk menggerakkan ke arah lebih baik, dari tidak bisa menjadi bisa, dari tidak tahu menjadi tahu. Perubahan tingkah laku tersebut bisa berupa dari aspek kognitif, afektif, maupun psikomotorik (Darmuki et al. 2017). Kegiatan Belajar Mengajar KBM merupakan bantuan yang diberikan pendidik agar peserta didik mendapatkan hasil belajar yang diinginkan. Hasil belajar dalam hal ini adalaj pemerolehan ilmu dan pengetahuan, penguasaan kemahiran dan tabiat, serta pembentukan sikap dan kepercayaan pada peserta didik sehingga peserta didik tumbuh dan berkembang dengan baik (Darmuki and Hidayati 2019)

Hasil belajar merupakan bagian terpenting dalam pembelajaran. Menurut Gagne dalam Aunurrahman (2013) menyatakan hasil belajar dapat berupa informasi verbal, yaitu kemampuan untuk mendeskripsikan sesuatu dengan kata-kata dengan jalan mengatur informasi-informasi yang relevan. Belajar konsep, prinsip, dan pemecahan masalah merupakan keterampilan intelektual atau pengetahuan prosedural yang diperoleh melalui penyajian materi disekolah. Kemampuan untuk memecahkan masalah-masalah baru dengan jalan mengatur proses internal masing-masing individu dalam memperhatikan, belajar, mengigat, dan berpikir merupakan pengertian dari ttrategi kognitif. Keterampialan motorik yaitu kemampuan untuk melaksanakan dan mengkoordinasikan gerakan-gerakan yang berhubungan dengan otot. Sikap, yaitu suatu kemampuan internal yang mempengaruhi tingkah laku seseorang yang didasari oleh emosi, kepercayaan-kepercayaan serta faktor intelektual. Dari pendapat tersebut dapat disimpulkan bahwa hasil belajar adalah gabungan dari pola-pola perbuatan, nilai-nilai, pengertianpengertian, sikap-sikap, apresiasi dan keterampilan, menyalurkan aktivitas kognitif sendiri yang melibatkan kemampuan internal yang mempengaruhi tingkah laku seseorang yang didasari oleh emosi, kepercayaan-kepercayaan serta faktor intelektual.

Menurut Arifin (2012) hasil belajar merupakan hasil dari suatu interaksi tindak belajar dan tindak mengajar. Hasil belajar dibedakan menjadi dua diantaranya dampak pembelajaran (prestasi), dan dampak pengiring (hasil). Hasil yang dapat diukur dalam setiap pelajaran (pada umumnya menyangkut domain kognitif), seperti tertuang dalam angka rapor dan angka dalam ijazah, hal ini merupakan pengertian dari dampak pembelajaran. Sedangkan Terapan pengetahuan dan kemampuan dibidang lain yang merupakan suatu transfer belajar (transfer of learning) merupakan pengertian dari dampak pengiring. Menurut Wasliman (2013) hasil interaksi antara berbagai faktor yang mempengaruhi, baik faktor internal maupun eksternal merupakan hasil belajar yang dicapai oleh peserta didik. Faktor internal itu sendiri merupakan 
faktor yang bersumber dari dalam diri peserta didik, yang memengaruhi kemampuan belajar. Sedangkan kecerdasan, minat dan perhatian, motivasi belajar, ketekunan, sikap, kebiasaan belajar, serta kondisi fisik dan kesehatan adalh Faktor internal. Membahas mengenai hasil belajar maka sangat berkaitan erat dengan proses pembelajaran yang dijalani siswa di sekolah, misalnya pembelajaran tematik.

Menurut Hadi Subroto (2000), pembelajaran tematik adalah pembelajaran yang diawali dengan suatu tema tertentu yang mengaitkan dengan pokok bahasan lain, konsep tertentu dikaitkan dengan konsep lain yang dilakukan secara spontan atau direncanakan baik dalam satu bidang studi atau lebih dan dengan beragam pengalaman belajar sehingga pembelajaran menjadi semakin bermakna. Sedangkan menurut Sukmadinata (2004) lebih memandang pembelajaran tematik sebagai suatu model pembelajaran dengan fokus pada bahan ajaran. Berdasarkan pendapat-pendapat tersebut dapat disimpulkan bahwa pembelajaran tematik atau pembelajaran terpadu adalah suatu sistem pembelajaran yang melibatkan dua atau lebih bidang studi dengan suatu tema yang sama, yang dapat lebih memberikan kesan mendalam bagi siswa sehingga kemampuan siswa memahami materi lebih meningkat.

Dalam pembelajaran tematik IPA di Sekolah Dasar diharapkan mampu menjadi wahana bagi peserta didik untuk mempelajari diri sendiri dan alam sekitar, serta prospek pengembangan lebih lanjut dalam menerapkannya di dalam kehidupan sehari-hari. Dalam proses pembelajaran lebih menekankan pada pemberian pengalaman langsung untuk mengembangkan kompetensi agar menjelajahi dan memahami alam sekitar secara ilmiah. pembelajaran IPA diarahkan untuk mencari tahu dan berbuat, sehingga dapat membantu peserta didik untuk lebih memahami tentang apa yang materi yang termuat di dalamnya. Sebagai seorang guru tentu saja menginginkan siswanya mendapatkan hasil belajar yang maksimal dari kegiatan belajar mengajar di sekolah khususnya pada pebelajaran IPA sehingga guru membutuhkan model pembelajaran yang efektif untuk menyampaikan materi-materi IPA salah satunya penerapan model Scramble. Harjasurjana dan Mulyati dalam Rahayu (2007) mengemukakan bahwa istilah "Scramble" di pinjam dari bahasa inggris yang berarti perbuatan, pertarungan, perjuangan. Istilah ini digunakan untuk sejenis permainan kata, dimana permainan menyusun huruf-huruf yang telah diacak susunannya menjadi suatu kata yang tepat. Secara umum model pembelajaran Scramble ini sepenuhnya melibatkan peran aktif siswa dalam aktivitas belajar yang dikemas dalam kegiatan bermain.

Macam-macam bentuk model pembelajaran Scramble menurut Damayanti (2010) sesuai dengan sifat jawabannya model ini terdiri atas bermacam-macam bentuk. Contoh pertama, Scramble kata, yakni sebuah permainan menyusun kata-kata dan huruf-huruf yang telah dikacaukan letaknya sehingga membentuk suatu kata tertentu yang bermakna misalnya: 
PTK, Vol.2 No.1 2021

ISSN: 2747-1977 (Print) / 2747-1969 (Online)

DOI: https://doi.org/10.53624/ptk.v2i1.42

rimataha $=$ matahari, bintang $=$ ngitban. Kedua, ada juga Scramble kalimat, yakni sebuah permainan menyusun kalimat dari kata-kata acak. Milsanya: Bintang-malam-penuh-ini= Malam ini penuh bintang. Terakhir, Scramble wacana, yakni sebuah permainan menyusun wacana logis berdasarkan kalimat-kalimat acak. Dengan penggunaan model pembelajaran scramble, siswa dapat dilatih berkreasi menyusun kata, kalimat, atau wacana yang acak susunannya dengan susunan yang bermakna dan mungkin lebih baik dari susunan aslinya. Ketiga bentuk pembelajaran model Scramble ini bisa disajika dalam satu kegiatan pembelajaran.

Di lihat dari fakta dan proses pembelajaran di SDN Koncer 1 Tenggarang Bondowoso Tahun 2020, khususnya kelas V dapat diidentifikasi permasalahan yang berkaitan dengan penyebab rendahnya hasil belajar siswa adalah guru kurang tepat dalam penggunaan model pembelajaran. Hasil pengamatan menunjukkan bahwa dalam proses belajar mengajar guru hanya menggunakan metode ceramah, guru kurang melibatkan siswa dalam menjelaskan tentang materi pembelajaran. Selain itu peserta didik yang kurang memperhatikan apa yang dijelaskan guru, mereka lebih banyak bermain dengan teman sebangkunya. Pembelajaran kurang menarik ataupun membosankan, siswa kesulitan memahami materi karena pembelajaran tidak didukung dengan media pembelajaran.

Dalam pembelajaran yang efektif dan bermakna peserta didik dilibatkan secara aktif, karena peserta didik adalah pusat dari kegiatan pembelajaran serta pembentukan kompetensi dan karakter. Model pembelajaran sangat erat kaitannya dengan gaya belajar peserta didik dan gaya mengajar guru. Usaha guru dalam membelajarkan peserta didik merupakan bagian yang sangat penting dalam mencapai keberhasilan tujuan pembelajaran yang sudah direncanakan. Oleh karena itu pemilihan berbagai metode, strategi, teknik maupun model pembelajaran merupakan suatu hal yang utama. Model pembelajaran yang tepat adalah model pembelajaran yang diterapkan pada pembelajaran bahan kajian atau pokok bahasan atau sub pokok bahasan tertentu dengan menggunakan waktu, dana tak begitu banyak dan mendapatkan hasil yang dapat diserap siswa secara maksimal.

Berkaitan dengan permasalahan yang ditemukan peneliti yaitu rendahnya hasil siswa pada pembelajaran tematik IPA, peneliti akan melakukan upaya untuk meningkan kualitas pembelajaran dengan penerapan metode pembelajaran Scramble, sehingga hasil belajar siswa dapat meningkat. Berdasarkan latar belakang yang teLah diuraikan di atas, permasalahannya yang akan dikaji dalam penelitian ini yaitu proses penerapan metode Scramble untuk meningkatkan kemampuan belajar tematika muatan IPA pada siswa kelas V (lima) SDN Koncer 1 Tenggarang Bondowoso Tahun 2020. 


\section{METODE}

Penelitian tindakan kelas ini dilaksanakan oleh guru kelas 5 SDN Koncer 1. Subjek penelitian ini adalah siswa SDN Koncer 1. Peneliti menggunakan Buku Tema 9: Benda-benda di sekitar kita sebagai media dalam pembelajaran tematik Muatan IPA tentang penggunaan sumber energi dalam kehidupan sehari-hari. Penelitian dilaksanakan pada tanggal 23 April 2020 (siklus 1) dan tanggal 07 Mei 2020 (siklus 2).

Karakteristik siswa-siswi kelas 5 yang dipilih sebagai subjek penelitian adalah kategori siswa aktif dan mau memecahkan masalah yang diberikan oleh peneliti. Namun karena kondisi tertentu keaktifan siswa tersebut mengalami kendala dalam penerapan materi di kelas. Siswa SDN Koncer 1 dengan jumlah keseluruhan 20 siswa yang terdiri dari 12 siswa perempuan dan 8 siswa laki-laki. Penelitian ini dilaksanakan dalam 2 siklus. Siklus I membahas materi tentang mengamati gambar tentang sumber energi air dan listrik, sedangkan siklus II menjelaskan materi tentang memahami jenis-jenis sumber daya alam. Setiap siklus terdiri dari 4 tahapan yaitu perencanaan, pelaksanaan, pengamatan, dan refleksi (Arikunto 2008).

\section{Siklus I}

Siklus I dilaksanakan pada hari Kamis tanggal 23 April 2020, dimulai dengan membuat RPP dan RPP yang sudah rencanakan sebelumnya dapat menjadi pedoman bagi peneliti sampai dimana masalah tersebut menjadi dasar untuk mengetahui masalah yang akan dipecahkan oleh peneliti. Pembelajaran perbaikan siklus I dilakukan sebanyak 1 kali pertemuan. Pada kegiatan perbaikan pembelajaran siklus I dilaksanakan dengan menggunakan penerapan metode Scramble tentang mengamati gambar tentang sumber energi air dan listrik.

Pada siklus I peneliti menggunakan metode observasi yang mana metode tersebut dapat menjadi salah satu teknik dalam mengumpulkan data yang nantinya akan mendukung peneliti ke siklus selanjutnya. Pada kegiatan observasi terkait RPP yang telah disusun oleh peneliti dengan beberapa kegiatan awal, kegiatan inti, serta kegiatan akhir yang ada di RPP tersebut. Penerapan tersebut dilaksanakan dengan melakukan kegiatan pembelajaran pada siswa-siswi yang dijadikan subjek yaitu siswa-siswi kelas 5 di SDN Koncer 1 Tenggarang Bondowoso.

Rencana refleksi dari perbaikan pembelajaran siklus 1 yaitu terdiri dari kepala sekolah yang ada di lembaga, teman sejawat atau guru senior dalam lembaga yang memiliki kompetensi. Teknik refleksi menggunakan wawancara untuk mendapatkan hasil yang maksimal.

\section{Siklus II}

Siklus 2 dilaksanakan pada hari Kamis tanggal 07 Mei 2020, dimulai dengan menyusun RPP perbaikan. Dalam penyusunan RPP pada siklus 2 merupakan tolak ukur dari pembelajarn pada siklus sebelumnya. Pada siklus II ini metode yang digunakan tetap seperti pada siklus I yaitu 
PTK, Vol.2 No.1 2021

ISSN: 2747-1977 (Print) / 2747-1969 (Online)

DOI: https://doi.org/10.53624/ptk.v2i1.42

menggunakan metode Scramble dengan menjelaskan materi memahami jenis-jenis sumber daya alam mata pelajaran IPA. RPP yang telah disusun akan dijadikan pedoman untuk pelaksanaan pembelajaran perbaikan siklus II.

Pada siklus II peneliti tetap menggunakan teknik observasi untuk mengumpulkan perbaikan proses pembelajaran. Observasi akan dilakukan pada saat proses pembelajaran perbaikan siklus II dengan memperhatikan keterkaitan pembelajaran dengan RPP yang telah disusun pada siklus I. Kemudian pada siklus II ini, kegiatan refleksi akan dilakukan oleh beberapa pihak yang terlibat diantaranya, kepala sekolah, teman sejawat atau guru senior yang ada dilembaga, teman sejawat antar lembaga yang memiliki kompetensi.

Menurut John Tukey (1961) Analisis data adalah prosedur untuk menganalisis data, teknik untuk menafsirkan hasil dari prosedur tersebut, cara merencanakan teknik pengumpulan data untuk membuat analisisnya lebih mudah, lebih tepat atau lebih akurat, dan semua mesin dan hasil statistik (matematika) yang berlaku untuk menganalisis data. Analisis data menggunakan analisis kualitatif yang menggambarkan perbandingan dan kemajuan belajar dari satu siklus ke siklus berikutnya.

\section{HASIL DAN PEMBAHASAN}

Dalam penelitian ini terdapat 2 siklus. Pelaksanaan penelitian hanya melibatkan 2 siswa, dikarenakan adanya wabah Virus Corona (Covid-19) yang sedang melanda. Virus Corona membuat peneliti melakukan pembelajaran dengan tempat seadanya saja yaitu dirumah, walaupun hasilnya belum sempurna dalam pembelajaran yang dilaksanakan peneliti. Tujuannya agar terhindar dari wabah COVID-19. Kegiatan pelaksanaan 2 siklus tersebut dapat diuraikan sebagai berikut:

1. Siklus 1

a. Tahap Perencanaan Tindakan

Penggunaan Model Scramble dalam pembelajaran didasarkan kepada hasil kajian pendahuluan. Kegiatan-kegiatan diantaranya:

1) Menyiapkan RPP yang akan digunakan selama proses pembelajaran di kelas.

2) Menyusun sekenario pembelajaran yaitu menyusun rencana pelaksanaan pembelajaran (RPP).

3) Merancang kegiatan belajar mengajar dengan menggunakan media gambar-gambar, potongan gambar yang akan dipasangkan pada kertas sebagaimana matode scramble yang digunakan yaitu siswa diminta untuk mencocokkan pertanyaan dengan cara diskusi.

4) Menyiapkan lembar observasi untuk mengamati kegiatan guru selama pembelajaran berlangsung. 
b. Tahap Pelaksanaan Tindakan

Pelaksanaan tindakan siklus I dilaksanakan hari Kamis, yaitu tanggal 23 April 2020 pukul 08.30 sd selesai dengan membahas tema kayanya negeriku tentang mengamati gambar tentang sumber energi air dan listrik. Sebagaimana dengan keadaan Jumlah peserta didik yang sebenarya sebanyak 20 orang, maka dalam pembelajaran ini peneliti hanya menggunakan 2 orang siswa, dikarenakan adanya aturan pemerintah yaitu "Stay At-Home " dengan tujuan menghindari penyebaran virus (Covid-19). Peneliti melaksanakan tindakan pembelajaran sesuai dengan skenario rencana pelaksanaan pembelajaran yang telah direncanakan. Guru Melaksanakan langkah-langkah RPP sesuai dengan tahap perencanaan.

1) Guru mengucapkan salam.

2) Guru membimbing siswa dalam berdo'a, kemudian guru tujuan pembelajaran, apersepsi dan ice, breaking.

3) Melaksanakan proses pembelajaran.

4) Pada kegiatan inti, guru menjelaskan materi pembelajaran dengan menggunakan media gambar yang sudah disiapkan di perencanaan.

5) Setelah itu, guru mengajukan pertanyaan-pertanyaan terkait materi pembelajaran yang sudah dijelaskan di awal kegiatan inti.

6) Untuk mengetahui tingkat pemahaman siswa terkait materi tentang sumber energi air dan listrik, Guru memberikan soal-soal berupa lembaran dengan langkah-langkah mencocokkan lembar soal dengan jawaban yang sudah teracak hurufnya.

7) Setelah siswa mengerjakan soal yang sudah di berikan oleh guru, guru melakukan penilaian.

8) Pada kegiatan penutup, guru memberikan kesimpulan terkait materi yang sudah diajarkan.

9) Guru memberikan umpan balik dari hasil permbelajaran.

10) Guru menyimpulkan sekaligus menindak lanjuti dengan memberikan tes formatif kepada siswa untuk melihat tingkat penguasaan materi.

c. Tahap Pengamatan

Pelaksanaan tahap ini dilaksanakan bersamaan dengan tahap pelaksanaan tindakan. Peneliti mencatat hal-hal yang berkaitan dengan keaktifan dan partisipasi siswa.

d. Tahap Refleksi

Pada tahap ini peneliti mengumpulkan dan melakukan identifikasi data yang diperoleh melalui lembar observasi dan catatan lapangan untuk kemudian dilakukan refleksi. Refleksi merupakan kegiatan untuk mengemukakan kembali apa yang sudah dilakukan. Kegiatan refleksi ini juga melibatkan kepala sekolah dan rekan guru sejawat. 
PTK, Vol.2 No.1 2021

ISSN: 2747-1977 (Print) / 2747-1969 (Online)

DOI: https://doi.org/10.53624/ptk.v2i1.42

\section{Siklus II}

Pada kegiatan perencanaan siklus 2 merupakan acuan di pembelajaran siklus 1 dengan beberapa kekurangan-kekurangan yang telah ditemukan pada siklus sebelumnya. Beberapa kegiatan yang dilakukan pada tahap ini antara lain penggunaan model Scramble dalam pembelajaran diantaranya:

a. Tahap PerencanaanTindakan

1) Menyiapkan media yang akan digunakan dalam pembelajaran.

2) Menyiapkan rencana pelaksanaan pembelajaran (RPP) siklus 2. Namun, RPP tersebut pada kegiatan inti kalimat-kalimatnya sudah lebih disederhanakan lagi.

3) Merancang perbaikan untuk proses pembelajaran pada siklus II berdasarkan refleksi dari siklus I.

4) Menyiapkan perangkat pembelajaran yang akan digunakan selama proses pembelajaran.

5) Menyiapkan hp untuk membuat video pembelajaran

b. Tahap Pelaksanaan Tindakan

Tahap ini dilaksanakan di kelas IV pada hari Minggu tanggal 07 Mei 2020 pada $10.00 \mathrm{~s} / \mathrm{d}$ selesai. Sebagaimana dengan keadaan Jumlah peserta didik yang sebenarya sebanyak 20 orang, maka dalam pembelajaran ini peneliti hanya menggunakan 2 orang sebagai objek pengganti siswa, dikarenakan adanya aturan pemerintah yaitu "At-Home" dengan tujuan menghindari penyebaran virus (Covid-19). Langkah-langkah kegiatan pembelajaran yang dilakukan adalah sebagai berikut:

1) Guru Melaksanakan langkah-langkah RPP sesuai dengan tahap perencanaan.

2) Guru mengucapkan salam.

3) Guru membimbing siswa dalam berdoa, kemudian guru tujuan pembelajaran, apersepsi dan ice,breaking.

4) Pada kegiatan inti, guru kembali menjelaskan materi pembelajaran yang berkaitan dengan memahami jenis-jenis sumber daya alam dengan menggunakan media gambar yang lebih menarik.

5) Ketika pelajaran berlangsung siswa mengikuti instruksi guru tetapi hanya ikut-ikutan apa yang dikatakan guru.

6) Pada kegiata selanjutnya guru menjelaskan kembali materi pembelajaran, pembelajaran sudah mulai kondusif.

7) Untuk mengetahui tingkat pemahaman siswa, guru memberikan soal berupa lembar kerja yang berisi soal dan jawaban yang beracak dengan cara mencocokkan jawaban dengan soal.

8) Pembelajaran berjalan dengan baik dan siswa sudah mengalami peningkatan dalam memahami proses pembelajaran. 
9) Di kegiatan penutup guru memberikan tindak lanjut dan umpan balik sebagai bentuk dari hasil proses pembelajarn yang telah berlangsung

10) Guru mengucapkan salam.

\section{c. Tahap Pengamatan}

Pelaksanaan tahap ini dilaksanakan bersamaan dengan tahap pelaksanaan tindakan. Peneliti mencatat hal-hal yang berkaitan dengan keaktifan dan partisipasi siswa.

\section{d. Tahap Refleksi}

Pada tahap ini peneliti mengumpulkan dan melakukan identifikasi data yang diperoleh melalui lembar observasi dan catatan lapangan untuk kemudian dilakukan refleksi. Refleksi merupakan kegiatan untuk mengemukakan kembali apa yang sudah dilakukan. Kegiatan refleksi ini juga melibatkan kepala sekolah dan rekan guru sejawat.

Dalam proses pembelajaran dari siklus 1 dan siklus 2 peneliti dapat menemukan beberapa perubahan dari setiap siklus yang mana setiap siklus adalah perubahan hasil belajar siswa, dengan demikian penggunaan model pembelajaran Scramble dirasa sudah berhasil dengan melihat dari siklus 2. Hasil penelitian ini sesuai dengan hasil penelitian sebelumnya yang menyimpulkan bahwa motode Scramble efektif meningkatkan hasil belajar siswa kelas IV di Madrasah Ibtidaiyah pada mata pelajaran IPA (Kholifah 2008).

Selain itu, peneliti juga menemukan kelebihan dan kelemahan dari penelitian ini terkait penerapan model Scramble ini. Adapun kelebihan dari penggunaan model pembelajaran Scramble yaitu semua siswa dapat terlibat dalam proses pembelajaran secara aktif. Penggunaan metode Scramble bagi siswa dapat menumbuhan solidaritas antar siswa juga dapat mendorong siswa dalam belajar yang kompetitif untuk memahami materi yang diajarkan. Di samping itu, penerapan model Scramble ditemui beberapa kendala yaitu guru memerlukan waktu yang cukup lama dalam mengimplementasikannya, memerlukan waktu yang panjang sehingga guru sulit menyesuaikannya dengan waktu yang telah ditentukan dan kegiatan yang dikemas dalam bentuk permainan biasanya menimbulkan suara gaduh. Hal tersebut jelas akan mengganggu kelas yang berdekatan.

Perubahan perilaku pada diri siswa ke arah yang lebih baik dapat dijadikan indikator bahwa siswa memiliki motivasi belajar. Keberhasilan guru dalam memotivasi siswanya mengikuti proses pembelajaran dapat dilihat dari perubahan perilaku siswa dan rasa tertarik untuk mengikuti pembelajaran yang disampaikan oleh guru. Peneliti memberikan kesimpulan bahwa dalam penerapan model Scramble dapat meningkatkan hasil belajar siswa dengan menjadikan kondisi kelas lebih kondusif, guru dan siswa dapat berkreasi melalui soal dalam bentuk permainan. Namun peneliti dalam menerapkan metode Scramble masih kesulitan dengan 
PTK, Vol.2 No.1 2021

ISSN: 2747-1977 (Print) / 2747-1969 (Online)

DOI: https://doi.org/10.53624/ptk.v2i1.42

adanya siswa yang ramai, siswa kebingunan dalam menjawab soal dikarenakan jawaban dari setiap soal berupa huruf acak, sehingga membuthkan waktu yang lama

\section{KESIMPULAN}

Penerapan model Scramble dapat meningkatkan hasil belajar siswa dengan menjadikan kondisi kelas lebih kondusif, guru dan siswa dapat berkreasi melalui soal dalam bentuk permainan. Hanya saja penerapan model Scramble dalam pembelajaran membutuhkan waktu yang lama dan guru harus lebih fokus mengkondisikan siswa agar kondisi kelas tetap kondusif dikarenakan pembelajaran dikemas dalam bentuk permainan yang sangat berpotensi menimbulkan kegaduhan di dalam kelas.

\section{DAFTAR PUSTAKA}

Arifin. 2012. Pengertian Hasil Belajar, (Online), (http://fatkhan.web.id/pengertian-hasilbelajar/), diakses pada 26 April 2020.

Arikunto. 2008. Penelitian Tindakan Kelas. Jakarta: PT Bumi Aksara.

Aunurrahman, 2013. Pengertian Hasil Belajar, (Online), (http://fatkhan.web.id/pengertianhasil-belajar/), diakses pada 25 April 2020.

Damayanti. (2010). Model Pembelajaran Scramble, (Online), (http://modelpembelajaranblog.wordpress.com/2015/12/02/model-pembelajaranscramble/), diakses pada 1 Mei 2020)

Darmuki, A. \& Hidayati, N.A. 2019. Peningkatan Kemampuan Berbicara Menggunakan Metode Kooperatif Tipe NHT pada Mahasiswa Tingkat I-A Prodi PBSI IKIP PGRI Bojonegoro Tahun Akademik 2018/2019. Jurnal Pendidikan Edutama. Vol. 6(2), hlm 9-18.

Darmuki, A., Andayani, Joko Nurkamto, Kundharu Saddhono. (2017). Evaluating Information-Processing-Based Learning Cooperative Model on Speaking Skill Course. Journal of Language Teaching and Reasearch. 8(1) pp. 44-51.

John Turkey. (1961). Teknik Analisis Data, (Online), (https://penelitianilmiah.com/teknikanalisis-data/), diakses pada 10 Juni 2020.

Kholifah, S. 2008. Peningkatan Hasil Belajar IPA Materi Sumber Energi melalui Metode Scramble dan Media Pagar pada Siswa Kelas IV MI Negeri 3 Semarang Tahun Pelajaran 2019/202. Salatiga: IAIN Salatiga.

Rahayu. (2007). Istilah Scramble, (Online), (http://tugassayasemua.blogspot.com/2016/06/model-pembelajaran-scramblemakalah.html), diakses pada 25 April 2020.

Subroto, H. (2000). Pengertian Pembelajaran Tematik, (Online), (http://digilib.unila.ac.id/582/3/Bab\%202.pdf, diakses pada 29 April 2020.

Sukmadinata. (2004). Pembelajaran Tematik, (Online). (http://tarpaniku.blogspot.com/2016/12/pengertian-tematik-tujuan-fungsi.html), diakses pada 29 April 2020.

Wasliman. (2007). Pengertian Hasil Belajar, (Online), (http://eprints.ums.ac.id/36968/1/NASKAH\%20PUBLIKASI.pdf), diakses pada 27 April 2020 . 